\title{
POTASSIUM DISTRIBUTION IN DRIP IRRIGATION WITH FERTIGATION FOR DIFFERENT INJECTION DISTANCES IN THE MAIN LINE
}

\author{
GUILHERME V. DO BOMFIM ${ }^{2}$, JUAN MANZANO ${ }^{3}$, BENITO M. DE AZEVEDO ${ }^{4}$, \\ DENISE V. VASCONCELOS ${ }^{5}$, THALES V. DE A. VIANA ${ }^{6}$
}

\begin{abstract}
The purpose of this research was to evaluate the $\mathrm{K}_{2} \mathrm{O}$ distribution uniformity by surface drip irrigation at Universitat Politecnica de Valencia, Valencia, Spain $\left(39^{\circ} 29^{\prime} \mathrm{N}, 0^{\circ} 23^{\prime} \mathrm{W}\right.$, $20 \mathrm{~m}$ ). The irrigation was performed by drip lines with not-compensated emitters, spaced $0.3 \mathrm{~m}$. The fertigation was realized using a fertilizer injector pump of electric action with injection of 0.25 h. The experimental design used completely randomized blocks with five treatments and four replications. The treatments consisted of injection in five distances, located at 10;20;30;40;50 m of the first drip line. Samples were collected in emitters located at the start, at $1 / 3$, at 2/3 and at the end of the drip lines. The nutrient concentration was determined by flame spectrophotometry. The Christiansen's uniformity coefficients (CUC), of distribution (DUC), of statistical (SUC) and of emission (eUC) were estimated. The $\mathrm{K}_{2} \mathrm{O}$ concentration and distribution decreased linearly with the increase of the injection distance. In all treatments, the CUC, SUC and DUC were described as 'excellent'. The eUC was described as 'recommended' only at smaller injection distances.
\end{abstract}

KEYWORDS: Uniformity. Chemigation. $\mathrm{K}_{2} \mathrm{O}$.

\section{DISTRIBUIÇÃO DE POTÁSSIO EM GOTEJAMENTO COM FERTIRRIGAÇÃO EM DIFERENTES PONTOS DE INJEÇÃO NA LINHA PRINCIPAL ${ }^{1}$}

RESUMO: Objetivando fornecer subsídios para os produtores aperfeiçoarem o manejo da fertirrigação em pequenas áreas, avaliou-se, na Universitat Politècnica de València, Valência, Espanha $\left(39^{\circ} 29^{\prime} \mathrm{N}, 0^{\circ} 23^{\prime} \mathrm{W}, 20 \mathrm{~m}\right)$, a uniformidade de distribuição do $\mathrm{K}_{2} \mathrm{O}$ via irrigação por gotejamento superficial em função da distância do ponto de injeção na linha principal. A irrigação foi efetuada por linhas laterais com emissores não compensantes, espaçados de $0,3 \mathrm{~m}$. $\mathrm{Na}$ fertirrigação, foi utilizada uma bomba injetora de fertilizante de acionamento elétrico, com o tempo de injeção de 0,25 h. O delineamento experimental foi o de blocos casualizados, com cinco tratamentos e quatro repetições. Os tratamentos consistiram em cinco pontos de injeção na linha principal, situados a: 10; 20; 30; 40 e 50 m da primeira linha lateral. Foram coletadas amostras em emissores localizados no início, a $1 / 3$, a $2 / 3$ e no final das linhas laterais. A concentração do nutriente foi determinada por espectrofotometria de chama. Foram estimados os coeficientes de uniformidade de Christiansen (CUC), de distribuição (CUD), estatístico (CUE) e de emissão (CUe). A concentração e a distribuição de $\mathrm{K}_{2} \mathrm{O}$ diminuíram linearmente com o aumento da distância do ponto de injeção. Em todos os tratamentos, o CUC, CUE e CUD foram classificados como ‘excelente'. O CUe foi classificado como 'recomendado' apenas na menor distância de injeção.

PALAVRAS-CHAVE: Uniformidade. Quimigação. $\mathrm{K}_{2} \mathrm{O}$.

\footnotetext{
${ }^{1}$ Parte do trabalho de Doutorado Sanduíche realizado na Universitat Politècnica de València, Valência, Espanha.

${ }^{2}$ Eng ${ }^{\circ}$ Agrônomo, Bolsista PNPD Doutor, Departamento de Engenharia Agrícola, Universidade Federal do Ceará/Fortaleza - CE,

Fone: (85) 3366-9754, guile01@ig.com.br

${ }^{3}$ Eng $^{\circ}$ Agrônomo, Prof. Doutor, Departamento de Ingeniería Rural y Agroalimentaria, Universitat Politècnica de València/Valência -

Espanha, juamanju@agf.upv.es

${ }^{4}$ Eng Agrônomo, Prof. Doutor, Departamento de Engenharia Agrícola, Universidade Federal do Ceará/Fortaleza - CE,

benitoazevedo@hotmail.com

${ }^{5}$ Eng ${ }^{\mathrm{a}}$ Agrônoma, Doutora, Departamento de Engenharia Agrícola, Universidade Federal do Ceará/Fortaleza - CE,

denisevasconcelos@hotmail.com

${ }^{6}$ Eng $^{\circ}$ Agrônomo, Prof. Doutor, Departamento de Engenharia Agrícola, Universidade Federal do Ceará/Fortaleza -

CE, thales@ufc.br

Recebido pelo Conselho Editorial em: 21-3-2013

Aprovado pelo Conselho Editorial em: 06-6-2014
}

Eng. Agríc., Jaboticabal, v.34, n.6, p. 1150-1161, nov./dez. 2014 


\section{INTRODUCTION}

Potassium is an essential macronutrient for plants by acting, among other functions for the transport of solutes protein synthesis and enzyme activation. Its deficiency affects the metabolism, with negative consequences on the nutritional quality of the product, mechanical stability and resistance to pests and pathogens (ARMENGAUD et al., 2009). The excess can also directly damage the crop by toxicity and indirectly by soil salinization (ARIENZO et al., 2009).

In modern agriculture, potassium used to fertilize crops of high economic value (melon, tomato, cotton, e.g.) it is almost exclusively applied by fertigation in drip irrigation systems (HERNÁNDEZ et al., 2009; REDDY \& ARUNA, 2010; SONG et al., 2009). Proper management of irrigation using emitters with good hydraulic characteristics and properly sized systems, provides high efficiency irrigation. When water is the only limiting factor, the uniformity of agronomic crop production depends on the uniformity of the available water in the root zone (LOPÉZ-MATA et al., 2010). There are indications that in poorly scaled systems and / or mishandled, the desuniform fertigation with excesses or deficits affects negatively the growth and crops productivity (ELHADY et al., 2010). To minimize or remedy such problems, it is important to evaluate the uniformity of distribution of nutrient by methods universally accepted as is the case of Christiansen uniformity coefficient of distribution, statistical and emission. These methods have been used for water irrigation (LOBOA et al., 2011) and in studies with $\mathrm{K}_{2} \mathrm{O}$, such as the performed by RIBEIRO et al. (2010).

The movement of nutrients along irrigation pipes in fertigation primarily occurs through mass flow, however at the ends of the lateral lines which hydraulic system is mainly laminar, the influence of the diffusion is more effective (OLIVEIRA \& VILLAS BOAS, 2008). So usually, the fertilizer concentration is higher in the first emitters due to the reduced time the nutrient solution takes to reach them. This behavior can cause changes in the uniformity of distribution of nutrients, as was evidenced by SOUSA et al. (2003), to assess the uniformity of distribution in time (2; 12; 22; 32; 42; $52 \mathrm{~min}$ ) and space (emitter at the beginning (2m), 1/3 (10 m), 2/3 (22 $\mathrm{m})$ and the end of the lateral line $(34 \mathrm{~m})$ ) of potassium chloride $(\mathrm{KCl})$ in a drip irrigation system. The authors found that the two most distant lines from the injection point showed less uniformity (average 76.3\%). As for the time noted that these lines had stable fertilizer concentration at 22 and 32 minutes, respectively.

One way to equalize the concentration of the nutrient in all emitters is to increase the injection time of the solution. Some authors recommend longer periods of injection (over 30 minutes) (OLIVEIRA \& VILLAS BOAS, 2008). However, in situations such as daily fertigation with high flow emitters, in cultures at an early stage of development and in plant with reduced water consumption, should not be recommended. In this situation, it is essential to test other types of management that aim to increase the uniformity of concentration of the nutrient provided by the emitters.

To subsidize producers in order to optimize the fertigation management in small areas, typical of agriculture practiced by family-based irrigators, this study aimed to evaluate the uniformity of potassium distribution fertigated by drip surface, according to the distance from the injection point on the main line.

\section{MATERIALS AND METHODS}

The experiment was conducted in Valencia Province, Spain, in an area belonging to the Universitat Politècnica de València (UPV), located at $39^{\circ} 29^{\prime} \mathrm{N}, 0^{\circ} 23^{\prime} \mathrm{W}$ and $20 \mathrm{~m}$ altitude.

The region climate according to the Koppen climate classification is type Csa characterized by hot dry summers and mild winters, with rainfall concentrated in spring and autumn and average temperature above $10^{\circ} \mathrm{C}$ in all months of the year (BOATA \& GRAVILA, 2012). 
The irrigation system was installed in the experimental area of surface drip type, consisting of rows of low density polyethylene (LDPE), consisting of pipeline, main, derivation and lateral. The main line contained drawer record, gauge with glycerin and injection points to allow control of fertigation and fertilizer injection at different distances. The injection was performed by a fertilizer injector pump of electric drive, model M15 3812001 (Hidroconta S.A), calibrated to operate at a rate of injection of $1 \mathrm{~L} \mathrm{~min}^{-1}$. The lateral lines have borne integrated emitters, and not compensating with individual flow of approximately $1.6 \mathrm{~L} \mathrm{~h}^{-1}$ at a nominal pressure of $100 \mathrm{kPa}$. The equation obtained in the laboratory to represent the flow versus pressure ratio was equivalent to: $\mathrm{y}=0.3353$ $\mathrm{x}^{0.6755}, \mathrm{R}^{2}=0.99$. The load loss along the derivation line was quantified in pressure taken at the beginning of the lateral lines evaluated $\left(\mathrm{L}_{\text {inicial }}\right.$ of $100.15 \mathrm{kPa}$ to $\mathrm{L}_{\text {final }}$ of $81.21 \mathrm{kPa}$, totalizing 18.94 $\mathrm{kPa}$ in $46 \mathrm{~m}$ ). The representative sketch of the irrigation / fertigation system can be seen in Figure1.

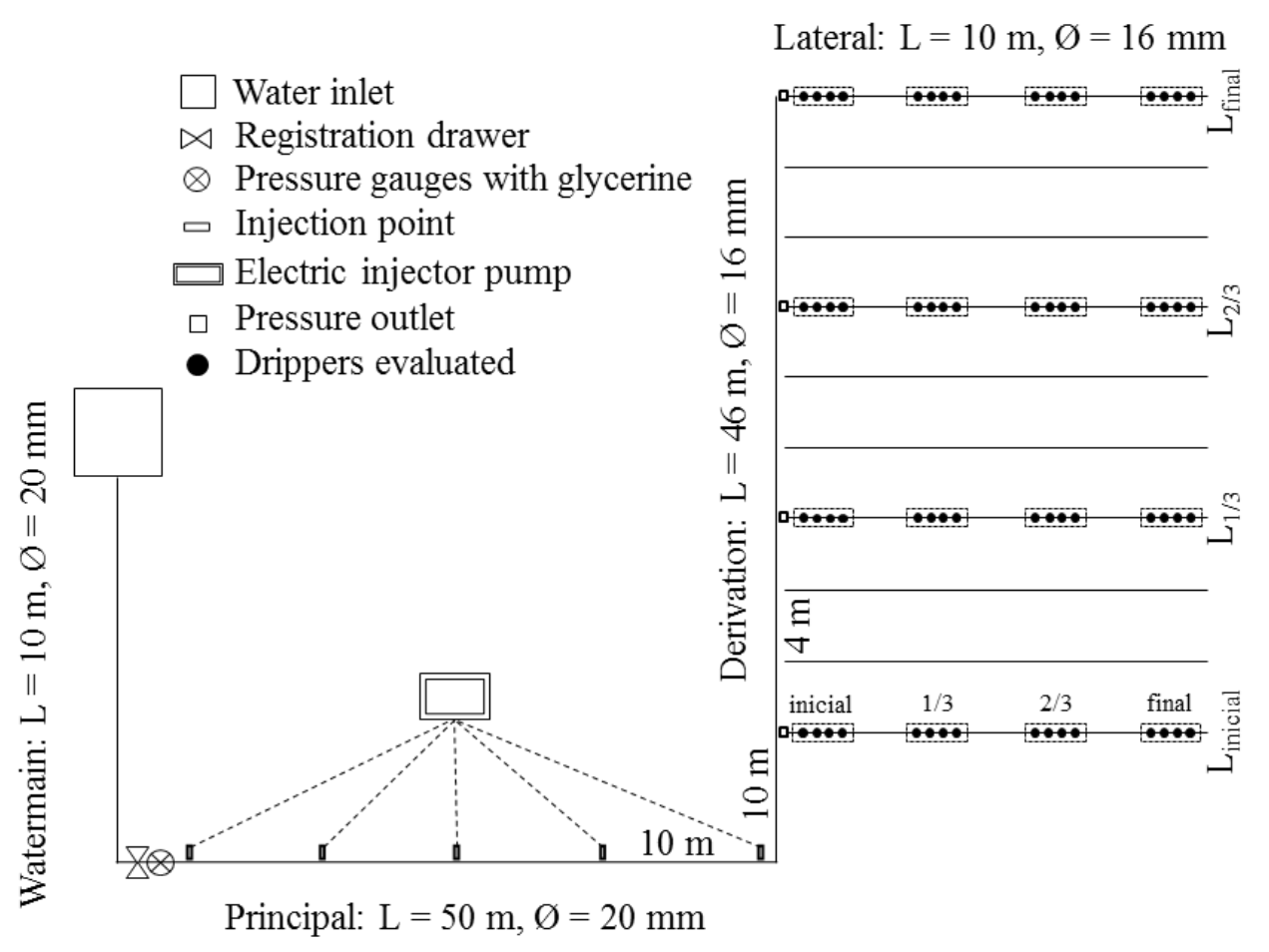

FIGURE 1. Representation of the superficial drip system and its main components, Valencia, Spain, 2012.

The experimental design was a complete randomized block with five treatments and four replications. Treatments consisted in five injection points of $\mathrm{K}_{2} \mathrm{O}$ on the main line, located at: 10, 20, 30, 40 and $50 \mathrm{~m}$ from the first side line.

The average data of air temperature, relative humidity, wind speed at $2 \mathrm{~m}$ and rainfall recorded on the assay day, May $2^{\text {nd }} 2012$, corresponded to $15.6{ }^{\circ} \mathrm{C}$ (maximum at $22.5{ }^{\circ} \mathrm{C}$ ) $69.6 \%$ (minimum 37.5\%), $0.84 \mathrm{~m} \mathrm{~s}^{-1}$ (maximum of $5.2 \mathrm{~m} \mathrm{~s}^{-1}$ ) and $0 \mathrm{~mm}$, respectively. These climatological parameters, especially the extreme values (recorded in the afternoon, while running the assay) of air temperature, wind speed and rainfall, for the respective possibilities variation in the emitters of operational restrictions on the collectors and of change in the collected volume remained stable during the differentiation of treatment, favoring the experiment.

Therefore, after the test with irrigation water, it was used in a single procedure $133.3 \mathrm{~g}$ of $\mathrm{K}_{2} \mathrm{O}$ in the form of white potassium chloride, diluted into a container with $15 \mathrm{~L}$ and injected in a range of $0.25 \mathrm{~h}$ after full operation in the irrigation system. The washing time of the pipes in each treatment was $0.1 \mathrm{~h}$. This management represented an application of $2 \mathrm{~kg} \mathrm{ha}^{-1}$ of $\mathrm{K}_{2} \mathrm{O}$ in $0.35 \mathrm{~h}(21$ minutes), simulating a daily fertigation in cultures with reduced water consumption, whose time of injection should not exceed the irrigation time. 
For the evaluation of uniformity of water distribution and $\mathrm{K}_{2} \mathrm{O}$ in the area, we used the methodology by KELLER \& KARMELI (1974), with the selection of 16 sampling points. Therefore, along of 4 lateral lines (the first, in one third and in two thirds of the length from the derivation line and in the last lateral line) solutions were collected in 4 points (each point formed by four adjacent emitters): the first, in one third and in two-thirds of the length of the lateral line and in the last.

The syrup volumes were collected in plastic tubes containers and measured in beakers and samples of $20 \mathrm{~mL}$ from each volume of the solution for subsequent chemical analysis were separated and stored. The $\mathrm{K}_{2} \mathrm{O}$ concentration (C), in $\mathrm{mg} \mathrm{L}^{-1}$ was determined by flame spectrophotometry in the laboratory of edaphology in UPV. In order to not exceed the maximum limit of the equipment, was held a prior dilution of the sample (50 times) with: $1 \mathrm{~mL}$ of potassium solution added to $2 \mathrm{~mL}$ of lithium chloride $(\mathrm{LiCl})$ and $47 \mathrm{~mL}$ of deionized water.

The variation coefficient of manufacturing $\left(\mathrm{VC}_{\mathrm{m}}\right)$, represented by the ratio between the standard deviation and the average flow $\left(\mathrm{L} \mathrm{h}^{-1}\right)$ was estimated to assess the quality of new emitters, which are classified as type $\mathrm{A}\left(\mathrm{VC}_{\mathrm{m}}<0.05\right)$ and type $\mathrm{B}\left(0,05 \leq \mathrm{VC}_{\mathrm{m}} \leq 0,1\right)(\mathrm{ABNT}, 2006)$; the linesource emitters (emitters in line) are classified as: good $\left(\mathrm{VC}_{\mathrm{m}}<0.1\right)$, medium $\left(0,1 \leq \mathrm{VC}_{\mathrm{m}} \leq 0,2\right)$ and marginal or unacceptable $\left(\mathrm{VC}_{\mathrm{m}}>0.20\right)$ (ASAE, 2003).

The uniformity of spatial distribution of water and $\mathrm{K}_{2} \mathrm{O}$ was estimated by the uniformity coefficient of: Christiansen (Equation 1) (PRADO et al, 2012.), distribution [eq. (2)] (BUSATO et al, 2012.), statistical [eq. (3)] (SILVA et al., 2012) and emission [eq. (4)] (ASAE, 2003).

$$
C U C=100\left(1-\frac{\sum_{i=1}^{n}\left|q_{i}-q_{m}\right|}{n q_{m}}\right)
$$

where,

CUC - Christiansen uniformity coefficient in \%;

$\mathrm{q}_{\mathrm{i}}$ - average flow in each dripper in $\mathrm{L} \mathrm{h}^{-1}$;

$\mathrm{q}_{\mathrm{m}}$ - average flow of drippers in $\mathrm{L} \mathrm{h}^{-1}$,

$\mathrm{n}$ - number of observations.

$$
D U C=100 \frac{q_{25 \%}}{q_{m}}
$$

where,

DUC - distribution uniformity coefficient in \%;

$\mathrm{q}_{25 \%}$ - the lowest average of quartile flows, in $\mathrm{L} \mathrm{h}^{-1}$,

$\mathrm{q}_{\mathrm{m}}$ - average flow of drippers, in $\mathrm{L} \mathrm{h}^{-1}$.

$$
S U C=100\left(1-\frac{S}{q_{m}}\right)
$$


where,

SUC - Statistical uniformity coefficient, in \%;

$\mathrm{S}$ - flow standard deviation, in $\mathrm{L} \mathrm{h}^{-1}$,

$\mathrm{q}_{\mathrm{m}}$ - average flow of drippers, in $\mathrm{L} \mathrm{h}^{-1}$.

$$
e U C=100\left[1,0-\frac{1,27 C_{v}}{\sqrt{n}}\right] \frac{q_{m i ́ n}}{q_{m}}
$$

where,

eUC - emission uniformity coefficient, in \%;

$\mathrm{C}_{\mathrm{v}}$ - coefficient of manufacturing variation;

$\mathrm{n}$ - number of emitters;

$\mathrm{q}_{\text {mín. }}$ - minimum emitter flow, in $\mathrm{L} \mathrm{h}^{-1}$,

$\mathrm{q}_{\mathrm{m}}$ - average flow of the emitter, in $\mathrm{L} \mathrm{h}^{-1}$.

To determine the uniformity coefficient, following similar procedure to that used by OLIVEIRA et al. (2003), the replacement of the flow $\left(\mathrm{L} \mathrm{h}^{-1}\right)$ was performed in the original concept, by the $\mathrm{K}_{2} \mathrm{O}$ concentration (mg L ${ }^{-1}$ ) samples.

Average values of the variables: VCm, C, CUC, DUC, SUC and eUC were subjected to analysis of variance by $\mathrm{F}$ test (up to $5 \%$ probability) and subsequent regression analysis by the method of orthogonal polynomials (levels of the factors are equally spaced), using the models: linear (L) and quadratic polynomial (Q). The equations were selected based on significance $\mathrm{F}$ test, in the highest coefficient of determination $\left(\mathrm{R}^{2}\right)$ and at the significance of the equations coefficients by the $t_{\text {student }}$ test.

The mean concentration data of $\mathrm{K}_{2} \mathrm{O}$ were plotted in 3D graphics to analyze the distribution of the nutrient along the evaluated lateral lines: $\mathrm{L}_{\text {inicial }}, \mathrm{L}_{1 / 3}, \mathrm{~L}_{2 / 3}$ and $\mathrm{L}_{\text {final }}$.

The uniformity coefficient for each treatment were classified as follows: for the CUC (BERNARD et al., 2006): higher than 90\% (excellent), from 90 to 80\% (good), from 80 to $70 \%$ (regular), from 70 to 60\% (bad) and less than 60\% (unacceptable); for DUC (MERRIAM \& KELLER, 1978) : Higher than 90\% (excellent), from 90 to 80\% (good), from 80 to $70 \%$ (fair) and less than 70\% (bad); to the SUC (BRALTS \& KESNER, 1983): from 100 to $90 \%$ (excellent), from 90 to $80 \%$ (very good) from 80 to $70 \%$ (fair), from 70 to $60 \%$ (bad) and less than $60 \%$ (unacceptable); for eUC (ASAE, 2003): from 90 to 80\% (recommended for uniform topography and inclination lower than $2 \%$ ) and from 85 to $70 \%$ (recommended for all spacing, with steep or wavy topography and inclination higher than $2 \%$ ).

\section{RESULTS AND DISCUSSION}

Table 1 shows the results of variance analysis of the variables related to the water and potassium uniformity distribution in which only the variables related to the $\mathrm{K}_{2} \mathrm{O}$ showed significant difference between treatments. 
TABLE 1. Summary of the variance analysis of the manufacturing variation coefficient $\left(\mathrm{CV}_{\mathrm{m}}\right)$, solution concentration (C, mg L ${ }^{-1}$ ) and Christiansen's (CUC, \%), distribution (DUC, \%), statistical (SUC, \%) and emission (eUC, \%) uniformity coefficients, for water $\left(\mathrm{H}_{2} \mathrm{O}\right)$ and potassium $\left(\mathrm{K}_{2} \mathrm{O}\right)$, Valencia, Spain, 2012.

\begin{tabular}{|c|c|c|c|c|c|c|c|c|c|c|c|c|}
\hline \multirow{3}{*}{ VS } & \multirow{3}{*}{$\mathrm{LG}$} & \multicolumn{11}{|c|}{ Mean Square } \\
\hline & & \multicolumn{5}{|c|}{$\mathrm{H}_{2} \mathrm{O}$} & \multicolumn{6}{|c|}{$\mathrm{K}_{2} \mathrm{O}$} \\
\hline & & $\mathrm{VC}_{\mathrm{m}}$ & CUC & DUC & SUC & eUC & $\mathrm{C}$ & $\mathrm{VC}_{\mathrm{m}}$ & CUC & DUC & SUC & eUC \\
\hline Treatment & 4 & $0.00^{\text {ns }}$ & $0.47^{\mathrm{ns}}$ & $1.41^{\mathrm{ns}}$ & $0.41^{\mathrm{ns}}$ & $3.87^{\mathrm{ns}}$ & $44.01^{* *}$ & $0.001^{* *}$ & $6.34^{* *}$ & $13.69^{*}$ & $19.71^{\text {** }}$ & $96.74^{*}$ \\
\hline Residue & 12 & 0.00 & 0.32 & 0.48 & 0.31 & 2.86 & 5.58 & 0.00 & 0.93 & 3.76 & 1.41 & 20.05 \\
\hline Total & 19 & - & - & - & - & - & - & - & - & - & - & - \\
\hline VC (\%) & - & 11.53 & 0.60 & 0.74 & 0.60 & 1.95 & 2.88 & 19.82 & 1.01 & 2.09 & 1.27 & 5.49 \\
\hline Average & - & 0.05 & 95.54 & 94.01 & 94.55 & 86.97 & 82.00 & 0.06 & 95.35 & 92.76 & 93.42 & 81.52 \\
\hline Linear (L) & 1 & - & - & - & - & - & $158.92^{* *}$ & $0.005^{* *}$ & $23.19^{* *}$ & $44.31^{* *}$ & $69.93^{* *}$ & $279.52^{* *}$ \\
\hline Quadratic (Q) & 1 & - & - & - & - & - & $5.22^{\mathrm{ns}}$ & $0.0009^{*}$ & $1.120^{\mathrm{ns}}$ & $8.96^{\mathrm{ns}}$ & $4.60^{\mathrm{ns}}$ & $92.67^{*}$ \\
\hline
\end{tabular}

The quality of emitter as to VCm (mean of 0.05) refers to the type 'B' (ABNT, 2006). For emitters on line as international classification (ASAE, 2003), the integrated drippers have 'good' hydraulic quality. For the water, as there was no significant divergence in relation to the VCm being very close to the ideal value heeded in Brazil ( $\mathrm{VCm}<0.5)$ and results considering the appropriate international classification, regarded as 'good', it is assumed that the variation occurred in the uniformity application of $\mathrm{K}_{2} \mathrm{O}$ should not have been due to the emitters manufacturing variation, but rather likely the variation in the system flow (emitters possibly clogged) and/or, especially, of the reduced settling fertigation time.

The average values of CUC, DUC and SUC were corresponding to 95.54, 94.01 and $94.55 \%$. The classification of water application uniformity is considered 'excellent' for all coefficients evaluated (BERNARDO et al., 2006; MERRIAM \& KELLER, 1978; BRALTS \& KESNER, 1983). The emission uniformity (eUC average of 86.97\%) is within the recommended range for all crops, spacing and topographies (ASAE, 2003). 2).

The $\mathrm{VCm}$ for $\mathrm{K}_{2} \mathrm{O}$ showed linear response with the distances from the injection point (Figure

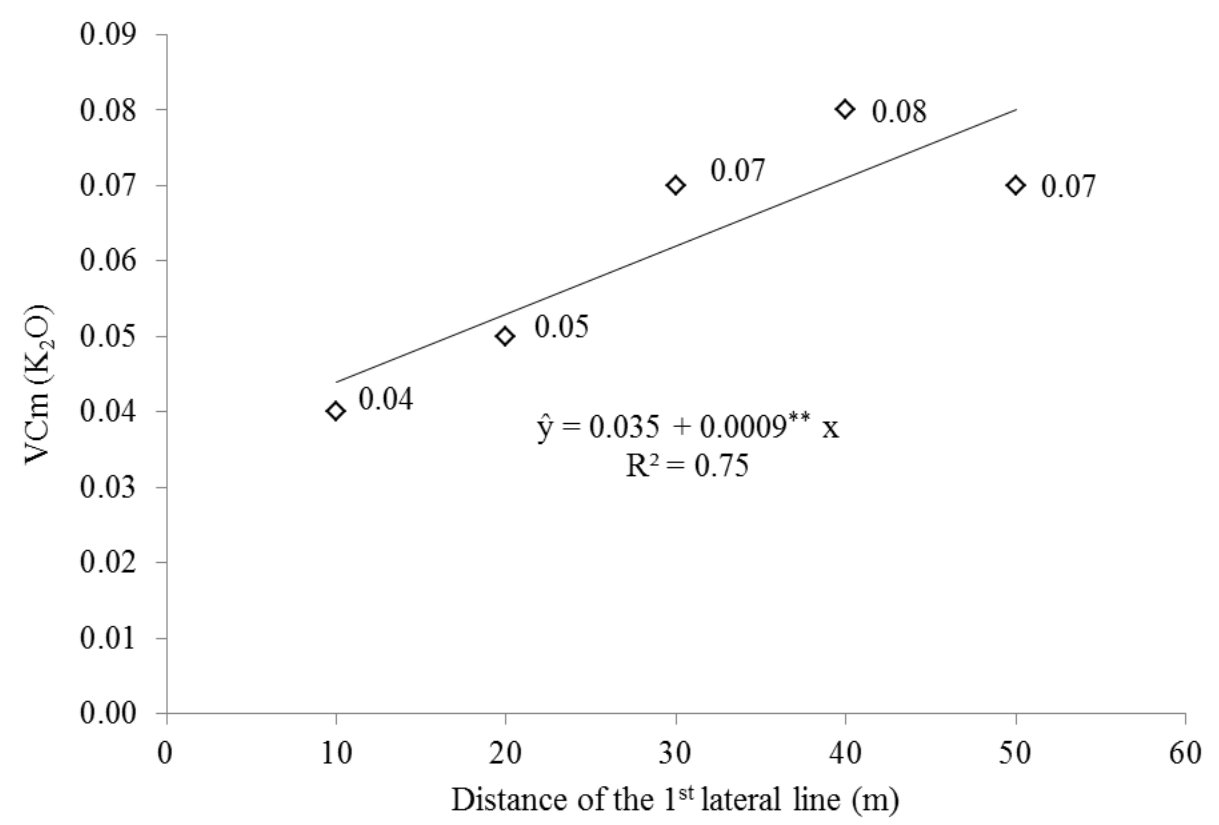

FIGURE 2. Manufacturing variation coefficient, VCm $\left(\mathrm{K}_{2} \mathrm{O}\right)$, according to the distance of the injection point, Valencia, Spain, 2012. 
The categorization of the $\mathrm{VCm}\left(\mathrm{K}_{2} \mathrm{O}\right)$ points to emitters type 'A' when one considers the distance of $10 \mathrm{~m}$ from the $1^{\text {st }}$ lateral and type 'B' for the other distances of injection (ABNT, 2006). To the international classification (ASAE, 2003), integrated drippers have 'good' hydraulic quality at all distances injection. Only the classification of ABNT (2006), for being more rigid than the international classification, suggests that the variation in uniformity of $\mathrm{K}_{2} \mathrm{O}$ application may be due to manufacturing variation of the emitters. However, based on the international classification (ASAE, 2003), considered as 'good', and in the results obtained only with water (Table 1), differences in $\mathrm{VCm}$, obtained with $\mathrm{K}_{2} \mathrm{O}$ concentration should have been main consequence as mentioned above, the short fertigation period.

The variation of $\mathrm{K}_{2} \mathrm{O}$ in the irrigation water $\left(\mathrm{mg} \mathrm{L}^{-1}\right)$ responded linearly to the distance from the injection point (Figure 3), with determination coefficient of 0.9 and highly significant coefficient on linear equation by $t_{\text {Student }}$ test.

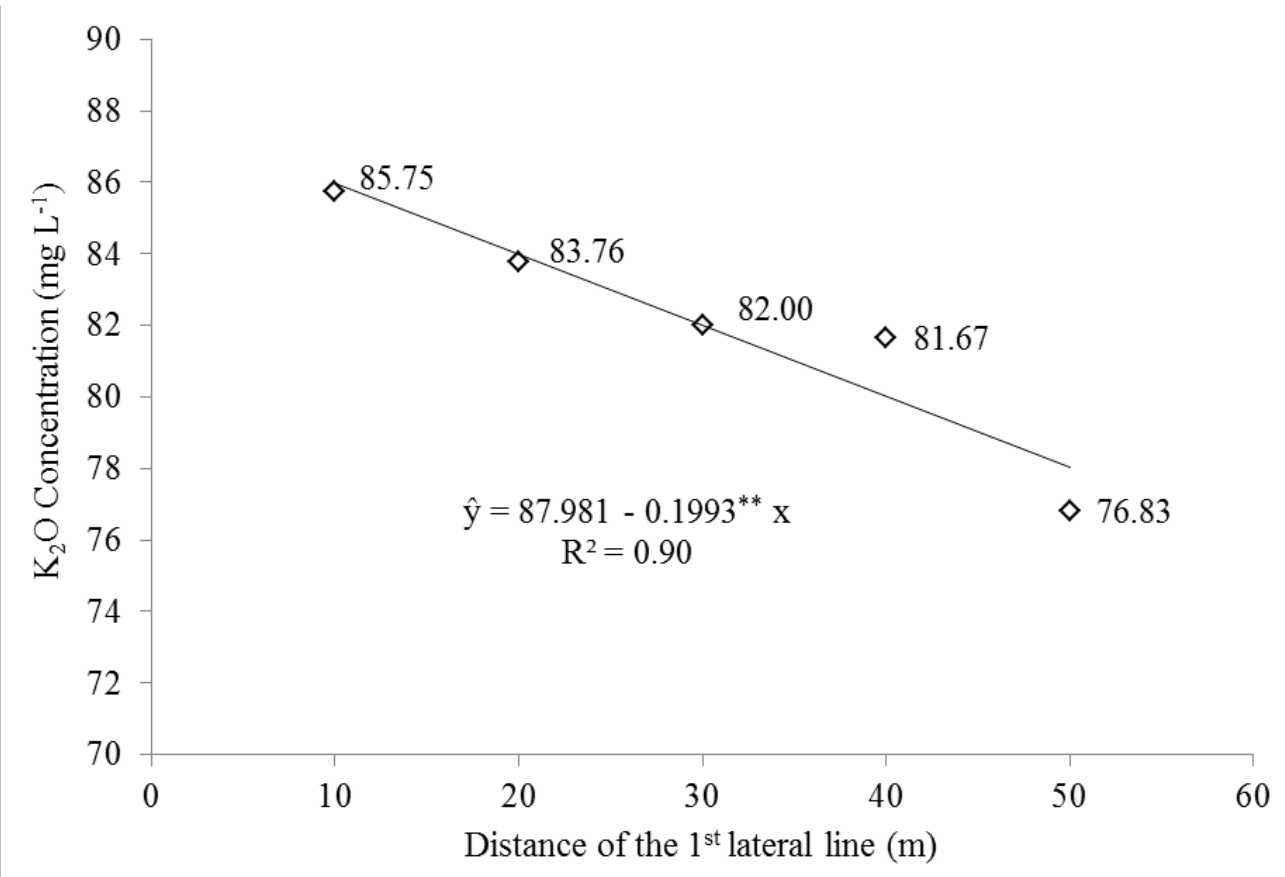

FIGURE 3. $\mathrm{K}_{2} \mathrm{O}$ concentration according to injection distance, Valencia, Spain, 2012. ${ }^{* *}$ Highly significant, $\mathrm{t}(0.01 \leq \mathrm{p}<0.001)$.

As closer the fertilizer injection in the lateral lines, bigger is the amount provided by the system. The highest the concentration $(10 \mathrm{~m})$ overcome the others in: $2.4 \%(20 \mathrm{~m}) ; 4.6 \%(30 \mathrm{~m})$; $5 \%(40 \mathrm{~m})$ and $11.6 \%(50 \mathrm{~m})$. The reducing concentration was more pronounced at $50 \mathrm{~m}$ in the first lateral line. Thus, as the fertigation time was relatively low, $\mathrm{K}_{2} \mathrm{O}$, to travel a greater distance until to the last lateral lines (longer period), may not have been completely removed from the pipes.

The $\mathrm{K}_{2} \mathrm{O}$ concentration along the lateral lines can be seen in Figure 4 . 

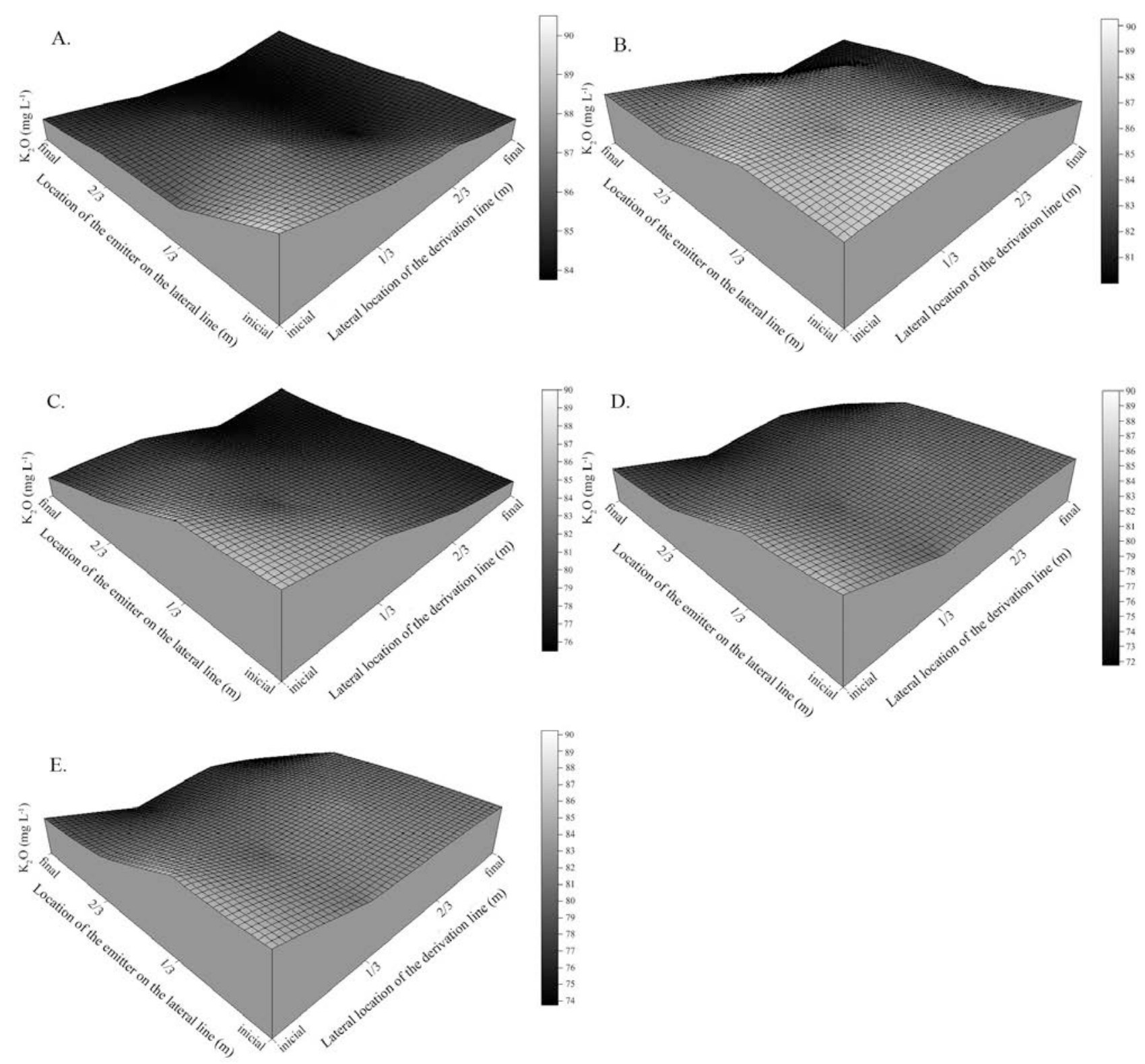

FIGURE 4. $\mathrm{K}_{2} \mathrm{O}$ concentration with injection point at $10 \mathrm{~m}$ (A), $20 \mathrm{~m}$ (B), $30 \mathrm{~m}$ (C), $40 \mathrm{~m}$ (D) and $50 \mathrm{~m}$ (E) from the first side line, Valencia, Spain, 2012.

At all points (Figure 4), the nutrient concentration is higher at the $1^{\text {st }}$ lateral and the first emitters, gradually decreasing in the lateral and the more distant emitters. In the last lateral line and in the one located at $2 / 3$ of derivation lengh, it is noticed that the reduction of the $\mathrm{K}_{2} \mathrm{O}$ concentration was more pronounced in the more distant emitters (2/3 and the end of the lateral line). In this location, it is likely that not every nutrient has been intercepted by the collectors, considering the lowest concentrations recorded. SOUSA et al. (2003) found that the $\mathrm{K}_{2} \mathrm{O}$ concentration in the irrigation water varied according to the distance of the laterals in relation to the injection point of the fertilizer. According to the authors, the most distant points tended to receive smaller amounts of fertilizer, especially in times of reduced injection $(0.2$ and $0.36 \mathrm{~h})$. CAMARGO (2010) also observed that at smaller injection times, the reduced $\mathrm{K}_{2} \mathrm{O}$ concentration was more pronounced in lateral lines further from the injection point. The first authors explain that such behavior is due to spatial effect in the fertilizers distribution since further they are from the injection point the longer it takes to reach the emitters and stabilize themselves.

The uniformity coefficient showed a linear response with the distances from the injection point (Figure 5). 


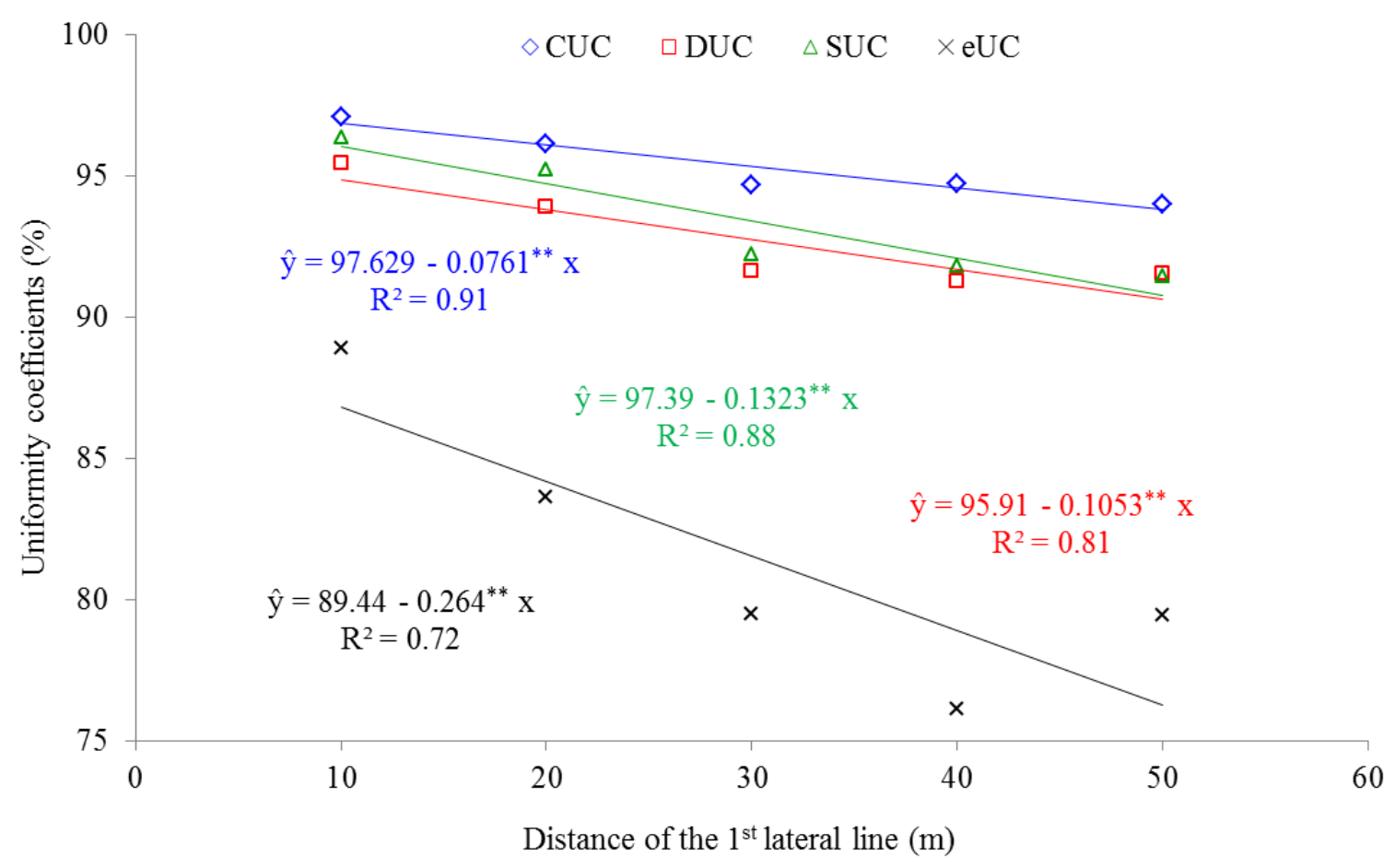

FIGURE 5. Christiansen's (CUC, \%), distribution (DUC, \%), statistical (SUC, \%) and emission (eUC, \%) uniformity coefficients, according to the injection distance, Valencia, Spain, ${ }^{* *}$ Highly significant, $\mathrm{t}(0.01 \leq \mathrm{p}<0.001)$.

2012.

Likewise the $\mathrm{K}_{2} \mathrm{O}$ concentration, the uniformity of distribution of the nutrient decreased with increasing distance from the injection point. Therefore, the shortest distance from the point of injection in relation of lateral lines provided a greater uniformity of distribution. The proportional superiority of the injection point at $10 \mathrm{~m}$ compared to the others was, on average $1.0 \%$ (20 m) $2.5 \%$ (30 to $40 \mathrm{~m}$ ) and 3.3\% (50 m) for CUC; 1.7\% (20 m) 4.2\% (30 minutes), 4.6\% (40 m) and 4.3\% (50 $\mathrm{m})$ for DUC; $4.4 \%$ (20 and 30m), 4.9\% (40 m) and 5.3\% (50 m) to SUC; 6.3\% (20 m) 11.8\% (30 to $50 \mathrm{~m}$ ) and $16.8 \%$ (40 $\mathrm{m}$ ) to the eUC.

Despite the statistical difference, the mean values of the treatments for the coefficients of Christiansen $\left(\mathrm{CUC}_{10 \mathrm{~m}}\right.$ of $97.12 \%$; $\mathrm{CUC}_{20 \mathrm{~m}}$ of $96.16 \% \mathrm{CUC}_{30 \mathrm{~m}}$ of $94.70 \% \mathrm{CUC}_{40 \mathrm{~m}}$ of $94.74 \%$; CUC $_{50 \mathrm{~m}}$ of $94.02 \%$ ), statistical (SUC $10 \mathrm{~m}$ of $96.35 \%, \mathrm{SUC}_{20 \mathrm{~m}}$ of $92.25 \%$; $\mathrm{SUC}_{30 \mathrm{~m}}$ of $92.24 \%$, $\mathrm{SUC}_{40 \mathrm{~m}}$ of $91.84 \%$; $\mathrm{SUC}_{50 \mathrm{~m}}$ of $91.44 \%$ ) and distribution $\left(\mathrm{DUC}_{10 \mathrm{~m}}\right.$ of $95.48 \%$; $\mathrm{DUC}_{20 \mathrm{~m}}$ of 93.89\%; DUC $_{30 \mathrm{~m}}$ of $91.64 \%$ of; $\mathrm{DUC}_{40 \mathrm{~m}}$ of $91.26 \%$ DUC $_{50 \mathrm{~m}}$ of $\left.91.53 \%\right)$ showed an 'excellent' uniformity rating (BERNARDO et al., 2006; MERRIAM \& KELLER, 1978; BRALTS \& KESNER, 1983). The lowest values of DUC, compared to the CUC and SUC are typical, since its estimation is a variation in function of the four lowest concentrations (lower quartile) compared to the total average concentration (SILVA et al., 2011). For eUC (eUC $10 \mathrm{~m}$ of $88.91 \%$; $\mathrm{eUC}_{20 \mathrm{~m}}$ of $83.62 \%$; eUC $\mathrm{efm}_{30 \mathrm{~m}}$ of $79.49 \%$; $\mathrm{eUC}_{40 \mathrm{~m}}$ of $76.12 \%$; $\mathrm{eUC}_{50 \mathrm{~m}}$ of $79.46 \%$ ), only the shortest distance is in the classification 'recommended '(ASAE, 2003), although numerically, the other values find themselves close to the recommended range.

The results obtained in the experiment agreed with those obtained by SOUZA et al. (2003), since the authors observed in smaller injection time $(0.2$ and $0.36 \mathrm{~h})$ that the uniformity of $\mathrm{K}_{2} \mathrm{O}$ was statistically lower on the lateral lines far away from the injection point.

It is noteworthy that there are emitters with various functions that promote good uniformity of irrigation (and fertigation), the example of self- compensating function, which stabilizes the flow in the variation pressure. In case of frequent emitters clogging (which could tend to change the flow of the system), this measure could be advantageous, since does not greatly burdening the system. 
However, not having that problem, it is better in fertigation with reduced intervals, injecting fertilizer as close to the lateral lines to provide a more uniform distribution.

Researches like SOUSA et al. (2003) have shown that the uniformity distribution is enhanced and stabilized by longer fertigation time, however under conditions that such recommendation can be considered a problem and cannot be attended, as the fertigation time above the crop's water requirements, alternative measures can be taken, in this case, reducing the distance from the injection point in the main line, as found in this study.

\section{CONCLUSIONS}

1. The variables related to uniform distribution of $\mathrm{K}_{2} \mathrm{O}$ (concentration and uniformity coefficient ) were statistically influenced by the treatments, showing decreased linearly with increasing distances from the injection point;

2. Producers may adopt the main line point nearest to the lateral line point to inject $\mathrm{K}_{2} \mathrm{O}$ by drip fertigation, aiming to increase the uniformity of potassium fertilizers application.

\section{ACKNOWLEDGMENTS}

To the Coordination of Improvement of Higher Education Personnel (CAPES) for grant the Doctoral Sandwich Abroad scholarship and the Universitat Politècnica de València (UPV), for providing the experimental area and all equipment and supplies needed for the research.

\section{REFERENCES}

ABNT. Associação Brasileira De Normas Técnicas. NBR ISO 9261. Equipamentos de irrigação agrícola: emissores e tubos emissores: especificações e métodos de ensaio. Rio de Janeiro, 2006. 17 p.

ARIENZO, M.; CHRISTEN, E. W.; QUAYLE, W.; KUMAR, A. A review of the fate of potassium in the soil-plant system after land application of wastewaters. Journal of Hazardous Materials, Amsterdam, v. 164, n. 2-3, p. 415-422, 2009.

ARMENGAUD, P.; SULPICE, R.; MILLER, A. J.; STITT, M.; AMTMANN, A.; GIBON, Y. Multilevel analysis of primary metabolism provides new insights into the role of potassium nutrition for glycolysis and nitrogen assimilation in arabidopsis roots. Plant Physiology, Bethesda, v. 150, n. 2, p. 772-785, 2009.

ASAE. American Society Of Agricultural Engineers. ASAE EP405.1 FEB03. Design and installation of microirrigation systems. St. Joseph: American Society of Agricultural Engineers, 2003. 6 p.

BERNARDO, S.; SOARES, A. A.; MANTOVANI, E. C. Manual de irrigação. 8. ed. Viçosa: UFV, 2006. 596 p.

BOATA, R. S.; GRAVILA, P. Functional fuzzy approach for forecasting daily global solar irradiation. Atmospheric Research, Amsterdam, v. 112, p. 79-88, 2012.

BRALTS, V.F.; KESNER, C.D. Drip irrigation field uniformity estimation. Transactions of the ASAE, St. Joseph, v. 26, p. 1369-1374, 1983.

BUSATO, C. C. M.; SOARES, A. A.;RAMOS, M. M.; REIS, E. F. dos.; BUSATO, C.

Dicloroisocianurato na prevenção do entupimento devido ao uso de águas ferruginosas em sistemas de irrigação por gotejamento. Semina: Ciências Agrárias, Londrina, v. 33, n. 1, p. 49-56, 2012.

CAMARGO, D. C. Uniformidade de distribuição de potássio utilizando diferentes fontes e concentrações na calda de fertirrigação em condições de campo. 2010. 66 f. Dissertação (Mestrado em Irrigação e Drenagem) - Centro de Ciências Agrárias, Universidade Federal do Ceará, Fortaleza, 2010. 
EL-HADY, O. A.; SHAABAN, S. M.; MOHAMEDIN, A. A. M. Impact of emission uniformity on nutrients uptake and water and fertilizers use efficiency by drip irrigated 15 years old Washington novel orange trees grown on a newly reclaimed sandy area. Journal of American Science, New York, v. 6, n. 7, p. 113-119, 2010.

HERNÁNDEZ, M. I.; CHAILLOUX, M.; MORENO, V.; MOJENA, M.; SALGADO, J. M. Nitrogen-potassium fertigation for protected cultivation of tomato (Solanum lycopersicum L.) and its effect on biomass accumulation and nutrient extraction. Cultivos Tropicales, Cuba, v. 30, n. 4, p. 71-78, 2009.

KELLER, J.; KARMELI, D. Trickle irrigation design parameters. Transactions of the ASAE, St. Joseph, v. 17, n. 4, p. 678-684, 1974.

LOBOA, J.; RAMÍREZ, S.; DÍAZ, J. E. Evaluación del coeficiente de uniformidad en cuatro emisores de riego usando filtración gruesa de flujo ascendente en capas. Revisa Escuela de Ingeniería de Antioquia, Medellín, n. 16, p. 29-41, 2011.

LÓPEZ-MATA, E.; TARJUELO, J. M.; JUAN, J. A. de.; BALLESTEROS, R.; DOMÍNGUEZ, A. Effect of irrigation uniformity on the profitability of crops. Agricultural Water Management, Philippines, v. 98, p. 190-198, 2010.

MERRIAM, J. L.; KELLER, J. Farm irrigation system evaluation: a guide for management. Logan: Utah State University, 1978. 271 p.

OLIVEIRA, M. V. A. M. de.; VILLAS BOAS, R. L.; GARCIA, C. J. B.; NASCIMENTO, F. R. Uniformidade de distribuição de potássio num sistema de irrigação por gotejamento quando aplicado por diferentes injetores. Irriga, Botucatu, v. 8, n. 3, p. 234-241, 2003.

OLIVEIRA, M. V. A. M. de.; VILLAS BOAS, R. L. Uniformidade de distribuição do potássio e do nitrogênio em sistema de irrigação por gotejamento. Engenharia Agrícola, Jaboticabal, v. 28, n. 1, p. 95-103, 2008.

PRADO, G. do.; COLOMBO, A.; OLIVEIRA, H. F. E. de.; FARIA, L. C. Uniformidade de aplicação de água de equipamentos autopropelidos de irrigação com aspersores de perfil radial triangular, elíptico e retangular. Engenharia Agrícola, Jaboticabal, v. 32, n. 3, p. 522-529, 2012.

REDDY, B. S.; ARUNA, E. Effect of doses and split application of nutrients through fertigation in Bt cotton (Gossypium hirsutum L.). Journal of Cotton Research and Development, Narrabri, v. 24, n. 1 , p. 59-63, 2010.

RIBEIRO, P. A. de A.; COELHO, R. D.; TEIXEIRA, M. B. Entupimento de tubos gotejadores convencionais com aplicação de cloreto de potássio (branco e vermelho) via duas qualidades de água. Engenharia Agrícola, Jaboticabal, v. 30, n.2, p. 279-287, 2010.

SILVA, E. N. da.; SILVEIRA, J. A. G.; FERNANDES, C. R. R.; DUTRA, A. T. B.; ARAGÃO, R. M. de. Acúmulo de íons e crescimento de pinhão-manso sob diferentes níveis de salinidade. Ciência Agronômica, Fortaleza, v. 40, n. 2, p. 240-246, 2009.

SILVA, E. R. da.; ZANINI , J. R.; CAZETTA, J. O.; FERRAUDO, A. S.; LEMOS FILHO, M. A. F. Uniformidade de distribuição de água em irrigação localizada com sistema de aeração, decantação e filtragem. Científica, Jaboticabal, v. 39, n. 1/2, p. 7-17, 2011.

SILVA, L. P. da.; SILVA, M. M. da.; CORREA, M. M.; SOUZA, F. C. D.; SILVA, Ê. F. de F. Desempenho de gotejadores autocompensantes com diferentes efluentes de esgoto doméstico. Revista Brasileira de Engenharia Agrícola e Ambiental, Campina Grande, v. 16, n. 5, p. 480-486, 2012. 
SONG, S.; LEHNE, P.; LE, J.; GE, T.; HUANG, D. Yield, fruit quality and nitrogen uptake of organically and conventionally grown muskmelon with different inputs of nitrogen, phosphorus, and potassium. Journal of Plant Nutrition, Singapore, v. 33, n. 1, p. 130-141, 2009.

SOUSA, V. F. de.; FOLEGATTI, M. V.; FRIZZONE, J. A.; CORRÊA, R. A. de L.; ALENCAR, C. M. Distribuição de fertilizantes em um sistema de fertigação por gotejamento. Revista Brasileira de Engenharia Agrícola e Ambiental, Campina Grande, v. 7, n. 1, p. 186-189, 2003. 